\title{
The promotion of participatory governance in the EU's external policies: compromised by sectoral economic interests?
}

\author{
Anne Wetzel* \\ Centre for EU Studies, Ghent University, Belgium \\ (Received September 2010, final version received February 2011)
}

Besides the more conventional top-down leverage and bottom-up linkage approach the EU uses a third way to promote democracy in third countries: promotion of democratic governance through functional cooperation in policy sectors. This governance model of democracy promotion has so far been studied only with regard to its effectiveness in target countries. In contrast to earlier research, this paper takes an 'input' perspective and asks whether adverse sectoral economic interests prevent the EU from consistent democratic governance promotion. Based on three case studies from the two policy sectors of environmental and fisheries policy, the paper concludes that EU democratic governance promotion is indeed inconsistent when sectoral economic interests are at stake. The governance model is thus subject to the same pattern of inconsistency as the leverage and linkage model with regard to economic interests.

Keywords: democracy promotion, democratic governance, public participation, European Union, functional cooperation, Common Fisheries Policy; Fisheries Partnership Agreements, Water Governance, Genetically Modified Organisms, European Neighbourhood Policy

\footnotetext{
*E-mail: Anne.Wetzel@UGent.be
} 


\section{Introduction}

The last years have not only seen the emergence of extensive European Union (EU) external governance $^{1}$ but also of an EU democracy promotion strategy that is directly connected to it. This strategy aims at deliberately making use of the functional ties established under the external governance agenda with third countries by transferring norms of democratic governance through sectoral cooperation. It was first outlined as one instrument among others in the 2001 European Commission's Communication on human rights and democracy promotion. There, the Commission acknowledged the potential of a sectoral approach to democracy promotion:

To promote human rights and democratisation objectives in external relations, the EU draws on a wide-range of instruments [...] Some are more innovative, and potentially underused, namely Community instruments in policy areas such [as] the environment, trade, the information society and immigration which have the scope to include human rights and democratisation objectives. These tools should be used in a coherent manner, to achieve synergy and consistency and to ensure maximum effective use of resources to promote sustainable development and respect for human rights and democratisation world-wide. ${ }^{2}$

The Commission's approach was subsequently supported by the Council. ${ }^{3}$

Shortly after the launch of the European Neighbourhood Policy (ENP), which can be regarded as the EU's most ambitious external governance project, the Commission stated that one of the goals regarding the participating countries is 'introducing sectoral reforms [...] in order to improve management and encourage the authorities to account for their decisions to those they administer'. ${ }^{4}$ Thus, the aim is not only to make sectoral governance in third neighbouring countries more effective, as standards of good governance would emphasize. ${ }^{5}$ By stressing the notion of accountability these reforms are also intended to make sectoral governance more democratic through the enhancement of popular control. ${ }^{6}$ As the Council and the Commission jointly pointed out, in the ENP Action Plans 'democracy building and support' do not only feature in the 'political section' but are also components of the other, i.e. the sectoral sections. ${ }^{7}$ There they are part of solutions for sectoral policy problems.

The goal of democratic governance promotion through functional cooperation is not restricted to the ENP. With regard to developing countries, the Commission outlined a similar approach by stressing the importance of mainstreaming democratic governance objectives into sectoral cooperation:

Democratic governance is to be approached holistically, taking account of all its dimensions (political, economic, social, cultural, environmental, etc.). [...] Accordingly, the concept of democratic governance has to be integrated into each and every sectoral programme. ${ }^{8}$ 
Again, democratic governance is acknowledged as a goal of cooperation. The intention is that it should form part of the sectoral cooperation that is in the first place directed at objectives such as reaching the Millennium Development Goals. Thus, the basic idea in both the ENP as well as in the approach towards developing countries is to 'use' sectoral functional cooperation, however motivated in the first place, in order to seek to develop norms of democratic governance to third countries.

In order analytically to grasp this new approach - which complements the more traditional bottom-up and top-down external democratization strategies - the governance model of democracy promotion has been introduced in the literature. ${ }^{9}$ Democratic governance promotion represents a more horizontal approach based on functional, transgovernmental cooperation in policy sectors. Through such cooperation, the sector specific rules of democratic governance embodied in the EU's acquis communautaire are promoted in the third country as parts of solutions for policy problems. The target actors are neither the third countries' governments nor civil society but sub-units of state administration. In contrast but not in opposition to democracy proper, which relates to the level of the polity and is often connected to certain institutional features such as general elections, the notion of democratic governance is defined at a sectoral level and comprises the three main principles of transparency, accountability, and participation. ${ }^{10}$ So far, it has been shown that the EU is fairly successful in promoting the formal adoption of rules of democratic governance in third countries. ${ }^{11}$ However, it has not been asked under what conditions the EU engages in democratic governance promotion in the first place. In particular, we do not know yet whether EU democratic governance promotion follows the same pattern of inconsistency that can be found in the top-down ${ }^{12}$ and bottom-up approaches ${ }^{13}$ to democracy promotion.

This article responds to the call for more empirical analysis of the EU's commitment to normative foreign policy goals in specific policy sectors. ${ }^{14}$ In particular, it will be examined whether adverse sectoral economic interests have an influence on the promotion of public participation as one element of democratic governance. In order to answer the question, the consistency of EU promotion of public participation in third countries will be analysed in three cases from the EU's external environmental and fisheries policy that are characterized by varying degrees of adverse sectoral economic interests. The article follows participatory democratic theories that stress the democratizing potential of public participation procedures. ${ }^{15}$ Participatory governance will here be generally understood as interaction of the public with institutions of the political system in the process of making binding decisions with the aim of influencing these decisions. ${ }^{16}$ While public participation is not necessarily 
successful it must be meaningful, i.e. participatory governance does not include instances of 'ceremonial' or 'pseudo' participation. ${ }^{17}$

The article proceeds in the following way. The next part deals with the explanations that have been offered in the literature in order to account for the EU's inconsistent democracy promotion through the intergovernmental and transnational channels. This provides the basis for case selection. In the subsequent empirical part, the three case studies cooperation on genetically modified organisms (GMO) and water governance with the Eastern European ENP countries ${ }^{18}$ and cooperation on fisheries policy under Fisheries Partnership Agreements (FPA) - will be presented and the EU's democratic governance promotion activities will be analysed. The article finishes with the conclusion that EU democratic governance promotion is inconsistent when important sectoral interests are concerned.

\section{Consistency of EU democracy promotion}

In a review of the existing literature regarding the consistency of EU general democracy promotion, Frank Schimmelfennig comes to the conclusion that '[d]espite the pervasive political and legal rhetoric of democracy and human rights promotion, actual policy seems to match rhetoric only when consistency is "cheap"; otherwise, it is driven by a host of other geopolitical, economic or security - interests' ${ }^{19}$ More particularly, authors have demonstrated that in cases where (soft) security issues arise the EU foregoes democracy promotion. ${ }^{20}$ It is also suggested that 'conflicting functional goals' may have led to a less consistent application of (positive) conditionality. ${ }^{21}$ Furthermore, it was shown that inconsistency in the EU's reaction to third states' non-compliance with democratic standards is mainly due to selfregarding concerns. ${ }^{22}$ With regard to democracy promotion through linkage it has been pointed out that the rather unsuccessful implementation of the bottom-up approach in the Southern Mediterranean countries can in part be attributed to EU Member States' (in particular, French and Spanish) 'political objections to a strengthening of the EU's democratization policy in the Mediterranean'. ${ }^{23}$

Existing studies on EU external democracy promotion provide different explanations for the observed inconsistencies. The most pervasive argument is that economic and security interests override democratization objectives. ${ }^{24}$ Another, related explanation is interdependence, which, if asymmetrical in favour of the third country, is assumed to lead to a decrease in democracy promotion. ${ }^{25}$ Taking into account that democratization may lead to 
instability and $\operatorname{war}^{26}$, the EU's reluctant democracy promotion has also been explained with the democracy-stability dilemma. ${ }^{27}$

EU democracy promotion has also been found to be dependent on target countries' geographic proximity. Starting from a democratic peace proposition and the EU's strategy to gain regional influence through integration it has been argued that 'the EU possesses a weighted utility function where its benefits from democracy in a neighbouring country are weighted more heavily than anywhere else'. ${ }^{28}$ The same tendency can be expected from a constructivist angle. Identity-based values and norms are supposed to 'become the more politically relevant in relations with external countries the closer these countries move toward membership'. ${ }^{29}$ Finally, the ambiguity of the template for democracy promotion has been named as a reason for inconsistent application of standards. ${ }^{30}$

Which expectations can we derive from the existing literature for democratic governance promotion? Given the strong emphasis that the literature puts on overriding interests, we can assume that 'only if no other concerns [...] are important in a given situation, 31 will the EU promote democratic governance. Which concerns should be considered as being 'important'? This paper employs a liberal view on democratic governance promotion in that it takes a "bottom-up" view of politics'. ${ }^{32}$ It thus follows recent empirical studies that have provided evidence for the influence of domestic sectoral interests on the EU's external relations in the fields of environment, development and trade. ${ }^{33}$ Since democratic governance promotion proceeds at a sectoral level, it can be expected that countervailing influential sectoral economic interests are an obstacle to it and that the EU's external relations 'in a given issue area will aim at achieving the material or immaterial goals which are pursued by the most influential domestic actors' ${ }^{34}$ Thus, it can be hypothesized that the more salient domestic interests are connected to the external dimension of the policy sector that would be hurt by the promotion of democratic governance the more likely it is that the EU forgoes this goal.

In this article, I will examine whether the presence of adverse sectoral economic interests has an influence on democratic governance promotion. In order to do so, a most similar case design will be combined with comparison of a case of the same type. Whereas the controlled comparison reveals the outcome of the key independent variable on the dependent variable, the latter may reveal whether causal paths are similar and increase confidence in generalization. ${ }^{35}$ The EU's policy will first be analysed in the environmental sector with regard to cooperation with Eastern European ENP countries on GMO and water issues. Environmental cooperation with Eastern European countries has been chosen because it 
allows keeping other explanatory variables stable for cases with different values on the key independent variable. Furthermore, according to the above mentioned explanations the context is rather favourable for democratic governance promotion. First, the environmental sector has a comparatively well developed acquis on participatory governance. There are even issue specific templates that the EU could promote in third countries. Thus ambiguity of standards is low. The templates are also embedded in international law and their promotion can thus be seen as legitimate. ${ }^{36}$ Furthermore, there is a 'misfit' in so far that the Eastern European ENP countries have not yet established comprehensive participatory arrangements in environmental decision making. Interdependence with regard to the two policy sectors and overall interdependence is not to the detriment of the EU. Environmental policy can generally be regarded as 'low politics', which excludes security interests as sources of inconsistency. Finally, although they are not on the way to accession, the Eastern European ENP countries are geographically close to the EU. Furthermore, they are part of an 'expanding system of functional regional integration'. ${ }^{37}$ Thus, overall, the conditions for democratic governance promotion are very favourable. However, with the field of GMO the sector contains an issue that is highly disputed and where economic interests are at stake. As will be shown in more detail below, some economic interests are not particularly compatible with democratic governance promotion. Since there are no comparably strong economic interests with respect to water governance the cases vary with regard to the key independent variable. ${ }^{38}$

The third case in the comparison - cooperation on fisheries policy under the FPAs - is similar to the GMO case. Since the cooperation on sectoral policy reform in third countries is part of a commercial arrangement there is a tension between commercial goals such as access to the resource and the promotion of governance objectives in order to enhance sustainability. At the same time, this case can also be regarded as low politics. Interdependence is not disadvantageous for the EU. There are EU internal and international templates on participatory governance in the fisheries sector. ${ }^{39}$ Geographically, however, the case is more diverse since it covers countries belonging to the African, Caribbean and Pacific Group of States, and also the ENP country Morocco.

\section{EU promotion of participatory governance}

\section{Environmental Policy}

The issue of public participation entered European environmental policy in the early 1990s. Today, the EU acquis on participative governance is well developed. This is true for general provisions such as the ones on Environmental Impact Assessment ${ }^{40}$, but there are also sector 
specific rules as will be outlined below. The EU's environmental policy has developed a very ambitious and multifaceted external dimension. One priority of the EU is the promotion of environmental cooperation with neighbouring countries and regions. ${ }^{41}$ With the Eastern European ENP countries, cooperation takes place in different frameworks, among others under the ENP sub-committees, but also in international fora such as the United Nations Economic Commission for Europe (UNECE). One of the overall aims of environmental cooperation with Eastern Europe is the improvement of environmental governance, which includes public participation in environmental decision-making.

\section{Genetically Modified Organisms}

Compulsory rules for public participation with regard to the deliberate release of GMO can be found in Article 9 of Directive 2001/18 that entered into force on 17 April 2002 and repealed an earlier Directive with non-binding rules on public participation. Similarly, the Regulation $1829 / 2003$ on genetically modified food and feed includes provisions on access to information and in Arts. 6(7) and 18(7) gives the public an opportunity to make comments on the opinion of the Authority that deals with an application for authorization.

While codifying participation rules in GMO matters internally, the EU is rather reluctant to promote them in Eastern European ENP countries. Although the Sixth Environmental Action Programme mentioned 'supporting the build up of regulatory frameworks in third countries where needed through technical and financial assistance' as a priority action regarding $\mathrm{GMO}^{42}$ the EU is not very active on this issue with regard to this particular region. Despite the fact that legislation on GMO and biosafety was still underdeveloped in the Eastern European ENP countries in the early and mid-2000s, cooperation on this issue was - in contrast to issues such as water quality, waste management and air pollution - not foreseen in the ENP strategy paper ${ }^{43}$ and is not mentioned in any of the ENP Action Plans with Eastern neighbours. ${ }^{44}$

Cooperation on participation regarding GMO issues is not only neglected but the EU has even deliberately obstructed attempts to promote participation rules related to GMOs in the Eastern European ENP countries. In the early 2000s, several countries in transition explicitly demanded an internationally binding template for participation rights in GMO matters in order to introduce respective rules 'at home'. For that reason, they suggested to amend the Convention on Access to Information, Public Participation in Decision-making and Access to Justice in Environmental Matters (Aarhus Convention) which hitherto contained only a very weak provision on public participation regarding GMO issues. ${ }^{45}$ For the EU as a 
signatory and party to the Aarhus Convention ${ }^{46}$ and an actor that officially wants to "work towards strengthening international environmental governance ${ }^{47}$, this would have been an ideal opportunity to aim at the transfer of the related acquis rules to third countries.

In fact, in the discussions on the EU negotiating mandate, several EU countries, in particular Belgium, Italy, Hungary, Portugal, Slovenia and Finland, supported a 'clear signal in favour of [...] detailed provisions on public participation in decision-making on GMOs consistent with existing Community legislation'. This opinion was, however, rejected by another group of member states, led by France. The latter explicitly favoured a non legallybinding option or a rather general obligation to promote, i.e. not guarantee, public participation. A similar conservative stance was taken by the European Commission. ${ }^{48}$ Given the conservative position of important EU member states, such as France and Germany, and the diversity of views within the EU, the negotiations proved to be extremely difficult and polarized. A final compromise on legally binding rules for participation on GMO issues was reached at last minute at the second meeting of the Parties in Almaty in 2005.

The reluctant EU position has been ascribed to two main factors. It was on the one hand seen as 'service to the GMO industry and the governments that support it'. On the other hand, observers pointed to pressure from the US government. ${ }^{49}$ One observer named a 'coalition of the biotechnology and trade lobby' as the source of the EU's tough stance. What is at stake regarding the promotion of public participation rules in GMO issues? In the European Union, the field of GMO is characterized by rather strict regulation and a sceptical public opinion. The former has led large biotech companies to relocate research activities, field trials and commercialization outside the EU. ${ }^{50}$ In parallel with the growing scepticism of Western European public opinion on GMO in the 1990s, transnational corporations such as Monsanto and Pioneer began to focus on Central and Eastern Europe where public awareness regarding this issue was much lower. Since agriculture is still a major economic sector this region, it is attractive for the western agricultural industry to start with field trials as a first step towards subsequent commercialization. Furthermore, the levels of regulation were very weak, in particular when compared to those of the EU. Since most Central and Eastern European countries lacked well-developed laws on this issue, there were hardly any hurdles to companies' activities. Transparency on field trials was often rather low. Lack of public protest was even seen in to be a market advantage. ${ }^{51}$ This provided a rather favourable environment for biotechnology corporations since they usually have a preference for low regulation. ${ }^{52}$

In the European Union, the big member states Germany, United Kingdom and France are leading players in biotechnology. ${ }^{53}$ The European Union itself is a target of lobbying 
activities of transnational bioindustry associations such as EuropaBio who enjoy 'good working relations with the Commission ${ }^{, 54}$ and are reported to have an influence on decision making. ${ }^{55}$ In 2003, the Competitiveness in Biotechnology Advisory Group with Industry and Academia was appointed by the Commission. It comprises 'representatives from all the various industry segments and from companies at every stage of company development together with entrepreneurial academics'. Besides the good access, internal unity of the European biotech sector has strengthened considerably during the 1990s. ${ }^{56}$ Firstly, in 1997 the European association EuropaBio was founded. Secondly, companies tend to enter into large coalitions. Thirdly, there is a trend for mergers within the sector. The global biotechnology industry structure is characterized by high concentration and internationalization where regional differences of interests disappear. Such a high concentration is generally assumed to be conductive to successful lobbying against strict regulations. ${ }^{57}$

With regard to the amendment of the Aarhus Convention, the world's largest biotechnology organization, the Biotechnology Industry Organization, which enjoys strong (financial) support of major biotech firms, maintains close relationships with US regulatory agencies $^{58}$ and has EuropaBio among its members expressed its discontent with new legally binding solutions. ${ }^{59}$ The same opinion was voiced by CropLife International. ${ }^{60}$ This global federation represents the plant science industry and also represents EuropaBio as one of its members. It was represented by two to three people in the negotiations who actively expressed 'conservative' standpoints. European Environmental non-governmental organizations (NGO), including NGOs from Eastern Europe, on the other hand have from the beginning called on EU environmental ministers to support the introduction of legally binding participation rules into the Convention ${ }^{61}$ and 'not to continue moving down a path of promoting weak biosafety frameworks in the non-EU region'. ${ }^{62}$ NGO representatives report that democratic governance issues related to GMO are in general weakly financed in EU and for NGOs it is difficult to receive funding. In Eastern Europe the situation is said to be even worse. Obviously, the coalition of environmental agents that has profited from and was carried by a strong negative public perception of agri-biotechnology and that 'succeeded in stemming the demand for deregulation and induced a strengthening of European GMO policy ${ }^{63}$ has much less influence when it comes to external relations. This can be explained by the lack of 'public outrage', i.e. the 'fear or anger a particular risk generates among a relatively large part of a country's population ${ }^{64}$ and the resulting decline of collective action capacity. 
As a result of the case study an additional factor emerged as potentially important for the outcome. Besides the biotech companies' and their business associations' initiatives, it must be kept in mind that GMO issues are subject to 'regulatory polarization' between the US and the EU with the US on the 'pro-agri-biotech' side and the EU on the other. ${ }^{65}$ US initiatives massively back the industry's activities in Eastern Europe. ${ }^{66}$ Moreover, it needs to be kept in mind that in 2003, after years of threatening to do so, the government of the USA, responding to domestic interests, and other GMO exporters filed suit against the EU before the World Trade Organization on GMO crops and food. ${ }^{67}$ There was thus a severe transatlantic tension over this issue. While one of the Commission's answers to this crisis was to signal an end of the unofficial moratorium on GMO release, the conservative stance in the Aarhus amendment negotiations can also be interpreted as a strategy to appease the US government that was very much against the amendment. Eventually, the Commission's stance reflected very much the position of DG Trade.

\section{Water Governance}

With the adoption of the Water Framework Directive in 2000, the EU established a framework for water protection and management whose success is seen to be dependent 'on information, consultation and involvement of the public'. ${ }^{68}$ Article 14 of this directive is dedicated to public information and consultation and demands that 'Member States shall encourage the active involvement of all interested parties in the implementation of this Directive, in particular in the production, review and updating of the river basin management plans'. More concretely, they shall ensure that 'they publish and make available for comments to the public, including users' certain specified documents related to a new or updated river basin management plan, and 'shall allow at least six months to comment in writing on those documents in order to allow active involvement and consultation'. River basin management plans in turn have to include 'a summary of the public information and consultation measures taken, their results and the changes to the plan made as a consequence'. ${ }^{69}$

In contrast to the issue of GMO, water governance in Eastern European ENP countries is not connected to comparably strong commercial interests that would be incompatible with the promotion of public participation. On the one hand, the water sector is an example that 'challenged the notion that the civil society sector acts only as a counterpart to the private sector'. In particular with regard to the issues of water pricing and full cost recovery environmental NGOs have joined the pro-pricing position of the water industry in the past. ${ }^{70}$ Furthermore, the preferences of stakeholders from the industry regarding the regulation of 
water issues are not necessarily equal but may even be contradictory, e.g. between agriculture and private water companies. ${ }^{71}$ On the other hand, Eastern European ENP countries are rather unattractive for international private water operators. Investments are seen to be risky due to the economic and political situation, weak regulatory frameworks, comparatively poor revenue streams due to low tariffs that are usually below operational costs and do not meet requirements of full cost-recovery, and a lack of political will to involve the private sector. Thus, Public-Private Partnerships in Eastern Europe, Caucasus and Central Asian (EECCA) countries with international participation remain at a low level. ${ }^{72}$

Public participation is one of the central themes of EU environmental cooperation with the Eastern neighbours and takes place in different frameworks. The EU does not hide its attempt to promote participative water governance in Eastern European ENP countries. On the contrary, the enhancement of public participation is regularly a component in water related projects. The 2007 Regional Indicative Programme for Eastern Europe expects as results of the planned activities among others the '[e]nhanced implementation of the EU Water initiative' and '[i]ncreased environmental awareness and civil society cooperation'. ${ }^{73}$ For example, the EU-financed project on 'Environmental Collaboration for the Black Sea' (20072009), which comprised Georgia, Moldova and Ukraine, on the one hand aimed to improve national legislation taking into account the water-related EU acquis and on the other hand explicitly included the improvement of public participation as one project goal. Adoption and implementation of water-related legislation is also the aim of another EU-financed project on 'Water Governance in the Western EECCA Countries' (2008-2010), which involves Belarus, Moldova and Ukraine, Armenia, Azerbaijan and Georgia. The work on these countries' legislation is seen as 'part of the process of convergence with EU environmental legislative and implementation principles'. As such, the project also intends to support public participation in decision-making processes. ${ }^{74}$ Thus, with regard to water governance, we see a clear intention of the EU to promote its norms on public participation which translates into concrete action.

\section{Fisheries Policy}

Governance has recently become a major topic in the EU's Common Fisheries Policy (CFP). Regarding participation in fisheries policy the basic Council Regulation for the reformed CFP, EC 2371/2002 now defines in Article 2.2 that fisheries policy 'shall be guided by [...] broad involvement of stakeholders at all stages of the policy [...]'. The topic of participatory governance was not only raised at a rhetorical level but concrete measures have been taken in 
order to substantiate it, in particular with the renewal of the Advisory Committee for Fisheries and Aquaculture (ACFA) in 1999 and the establishment of Regional Advisory Councils (RAC) in 2002. Furthermore, there exists a Sectoral Dialogue Committee on sea fisheries.

The EU's CFP has developed an external dimension. Clearly, the fisheries agreements are its most important aspect. ${ }^{75}$ Their present design is the result of a reform process in the year 2002. This reform aimed at a new approach towards third countries. In contrast to the much criticized 'pay, fish and go' approach of the existing fishing agreements, new partnership agreements were designed with a 'focus on cooperation to promote sustainable fishing, just as in our own waters' ${ }^{76}$ With their inclusion of dialogue and the setting aside of a share of the EU's financial contribution in order to 'to support the sectoral fisheries policy in the third country with a view to introducing responsible and sustainable fishing ${ }^{\text {,7 }}$ the agreements have a dual aim. Besides the commercial dimension there is the objective of 'projecting the Community 'acquis' in multilateral and bilateral arenas'. 78

The new external dimension of the CFP has been implemented since 2003. Today, all fisheries agreements with financial compensation are FPAs and in all of them, a percentage of the EU's financial contribution is earmarked for fisheries sector support in the respective third country. The third countries' progress with sector reforms is regularly discussed in Joint Committees on the basis of a country specific 'sectoral matrix' (matrice sectorielle). An analysis of the available minutes of the Joint Committees ${ }^{79}$ shows that issues of participation do not play a role in these meetings. In no instance did the EU refer to or even demand the enhancement of stakeholder participation with regard to fisheries in the third country. This is also acknowledged by interview partners. The same picture emerges from the sectoral matrices that the author was able to obtain. This does not imply that single matrices do not refer to arrangements to extend stakeholder participation. For example the matrix of GuineaBissau makes a reference to the strengthening of participative management committees (comités de gestion participative). However, as interview partners confirmed, there is no systematic attempt by the EU to encourage third countries to establish such arrangements. On the contrary, the EU explicitly rejects the promotion of governance norms through FPA: 'Some of the expectations placed on FPAs are unreasonable: they are there to support and assist, but they are not a tool for imposing what we think are the 'right' policies or governance systems on our partners. Their sovereignty is paramount. ${ }^{80}$

At first sight this statement seems to point to conflicting norms, i.e. democratic governance promotion vs. non-interference into the affairs of a sovereign state. However, even though the EU might have some leverage in some of the FPA countries, there would be 
no possibility to 'impose' governance reforms. Eventually, the third countries are free to spend the compensation from the FPAs as they want. Furthermore, given that the EU has an official democracy promotion policy in place which explicitly rejects the imposition of democracy from the outside ${ }^{81}$ and has democracy and human rights clauses in all its general agreements with third countries the reluctance to participatory governance promotion can rather be attributed to the opinion that it would make matters much more complicated as one interviewee judged. Fisheries agreements first and foremost remain commercial agreements. They are the result of negotiations on quota and financial compensation and there are diverse interests connected to them. The 2002 Commission Communication on FPAs states that apart from the overall aim of promoting sustainable fisheries, the specific objective of the CFP with regard to the Fisheries Agreements is 'to maintain the European presence in distant Fisheries and to protect European fisheries sector interests' ${ }^{82}$ The Council endorsed this objective with a view to employment and those European regions that are highly dependent on fisheries. ${ }^{83}$

The FPAs in their present form mainly serve the catching sector's interests. In particular the fleets from Spain, Portugal, Italy and France benefit from them. At EU level, these interests are represented by Europêche as the "vehicle through which the national fishermen's organizations agree their official representation vis-à-vis the Commission' ${ }^{84}$ In its position on the 2002 sector reform this group attached 'utmost importance' to the CFP's external dimension and pointed to 'the essentially commercial character' of fisheries agreements. ${ }^{85}$ In 2009, Europêche rejected any change of the CFP's external objectives and stated that the external dimension 'must continue to target upholding Community fishing fleets' interests in third countries' ${ }^{86}$ The French Union of the Armateurs à la Pêche demanded in 1998 that the EU should pursue 'an aggressive, dynamic and expansionist policy in the matter of fishing agreements. It no longer suffices to safeguard what already exists, [the EU] should develop what could be' ${ }^{87}$ The catching sector was the dominant pressure group in the early 2000s and still is rather influential. There are strong informal contacts between fisheries lobbyists and some national Council delegations. Partly, these circles have evolved through a common university education of its members and now persist. In general, the CFP is characterized as 'rather strong horizontal coordinating governance arrangement [...] between policymakers, fisheries managers and the fisheries sector' where the inner circle is made up of a limited number of actors, i.e. fishers and policymakers. ${ }^{88}$ Fishing interests have also long been organized at the national level and are viewed to be even more influential on CFP development than European organizations. ${ }^{89}$ They enjoy a high level of political salience that 
does not necessarily match statistical indicators. ${ }^{90}$ In contrast to the GMO case, external sectoral interests are not involved in the fisheries case.

Calls on the EU to promote participatory governance come from European NGOs such as the Coalition for Fair Fisheries Arrangements, some members of the European Parliament, and - from the outside - third country fisheries organizations. ${ }^{91}$ They are often part of a more comprehensive development agenda for the third countries. However, these demands are not reflected in the EU's policy. This is not least due to the worse access points for these actors: 'in an area of Commission competence, where DG Fisheries is in the lead [and DG Development marginalized], and where Council considerations are focused on fish rather than development, there is little formal opportunity for development inputs to be made'. ${ }^{92}$ Interestingly, however, the ACFA as the official consultative committee of the Commission on fisheries that includes representatives from industry but - since its reform in 1999 - also environmental and development NGOs has recently suggested that through the FPAs 'the EU should promote transparency and stakeholder participation, two important aspects recognized by the code of conduct for responsible fishing of the FAO'. ${ }^{93}$ It remains to be seen whether this position will finally be reflected in the future EU policy on cooperation under the FPAs.

\section{Conclusions}

The promotion of democratic governance through sectoral cooperation offers the EU a third, alternative way to further democratization objectives in third countries. In particular in contexts where top-down leverage and bottom-up linkage strategies reach their limits ${ }^{94}$ the governance approach with its focus on the transfer of functional solutions for policy problems opens a 'back door' for democracy promotion. Whereas research has shown that the EU is able to induce the adoption of rules of democratic governance in third countries ${ }^{95}$ this article has demonstrated that it does not always make use of this potential. After investigating EU democratic governance promotion in three cases with different levels of adverse interests, it can be concluded that the governance model is subject to the same pattern of inconsistency as the linkage and leverage model.

[Table 1 about here]

In cases such as cooperation on water governance with Eastern European ENP countries where no significant interests of EU domestic actors or other important external actors are hurt by the promotion of rules of democratic governance the EU puts emphasis on them. The 
two cases of cooperation on GMO with Eastern European ENP countries and cooperation on fisheries policy under FPAs, however, showed that the EU does not only neglect democratic governance promotion when sectoral interests would be hurt but even actively rejects such demands. While in the GMO case there are also strong external sectoral interests that may have influenced the result, no such interests are present in the fisheries case. Thus, strong external sectoral interests do not seem to be decisive for the inconsistency of EU democratic governance promotion. ${ }^{96}$ Summing up, the EU's democratic governance promotion policy is likely to be inconsistent when significant adverse sectoral economic interests are at stake.

\section{Acknowledgements}

The research for this paper has been undertaken within the NCCR Democracy. Financial support by the Swiss National Science Foundation is gratefully acknowledged. The author would like to thank Sandra Lavenex, Frank Schimmelfennig, Ulrich Sedelmeier, Tina Freyburg, the European politics research group at ETH Zurich, the participants of the Oxford Politics \& IR Graduate Research Workshop 2009, the panel participants and audience at the 2010 ISA Annual Convention, in particular Thomas Legler, and two anonymous reviewers for valuable comments. The empirical parts of the article are partly based on interviews conducted with officials of the European Commission in Brussels, in particular DG Environment, DG MARE and DG Development ; the Council Secretariat in Brussels; Directorate Agriculture and Fisheries; and representatives from non-governmental organizations based in Belgium, Ukraine, and Moldova, between 2007 and 2011.

\section{Notes}

\footnotetext{
${ }^{1}$ Lavenex, 'EU External Governance'.

2 European Commission, 'European Union's Role in Promoting Human Rights and Democratisation', 6, emphasis added.

${ }^{3}$ Council, 'Conclusions on Human Rights and Democratisation', III, IV.

${ }^{4}$ European Commission, 'Governance in the European Consensus on Development', 16, emphasis added.

${ }^{5}$ Kaufmann, Kraay, and Mastruzzi, 'Governance Matters VIII', 6.

${ }^{6}$ Beetham, Democracy and Human Rights, 155-156.

${ }^{7}$ European Commission and Council, 'Democracy building', 26.

${ }^{8}$ European Commission ,'Governance in the European Consensus', 6.

${ }^{9}$ Freyburg et al. 'EU Promotion of Democratic Governance'.

${ }^{10}$ Freyburg, Skripka, and Wetzel, 'Democracy between the Lines'.

${ }^{11}$ Freyburg et al. 'Democracy Promotion', in this volume.

${ }^{12}$ Maier and Schimmelfennig, 'Shared Values'; Olsen, 'Promotion of Democracy'; Olsen 'The European

Union'; Smith, European Union Foreign Policy, 165-167; Warkotsch, 'Non-Compliance'.

${ }^{13}$ Crawford, 'The European Union'; Jünemann, 'From the Bottom to the Top'; Youngs, 'The European Union', 56-57.

${ }^{14}$ Orbie 'Civilian Power Europe', 126.

${ }^{15}$ Held, Models of Democracy, 209-215, Schmidt, Demokratietheorien, 236-253.

${ }^{16}$ Friedrich, 'Old Wine', 5; Schmitter, 'Participation', 56.

${ }^{17}$ Verba, 'Democratic Participation', 55-56; Verba, Small Groups, 220-221.

${ }^{18}$ Armenia, Azerbaijan, Georgia, Moldova, Ukraine; all of them are considered to be 'European' countries by the European Commission, see http://europa.eu/abc/european_countries/others/index_en.htm (01.12.2010).

${ }^{19}$ Schimmelfennig, 'Europeanization beyond Europe', 15.

${ }^{20}$ Olsen, 'Promotion of Democracy'; Olsen 'The European Union'.
} 
${ }^{21}$ Maier and Schimmelfennig, 'Shared Values', 40.

${ }^{22}$ Warkotsch, 'Non-Compliance'.

${ }^{23}$ Jünemann, 'From the Bottom to the Top', 102.

${ }^{24}$ Schraeder, 'State of the Art', 33-34; Jünemann and Knodt, 'Explaining EU Instruments', 353-355; Olsen,

'Promotion of Democracy', 163.

${ }^{25}$ Jünemann and Knodt, 'Explaining EU Instruments', 357-358.

${ }^{26}$ Snyder, From Voting to Violence.

${ }^{27}$ Powel, 'A clash of Norms'; Andrés Viñas, 'EU's Democracy Promotion Policy'.

${ }^{28}$ Warkotsch, 'Non-Compliance', 230-231.

${ }^{29}$ Maier and Schimmelfennig, 'Shared Values', 45.

${ }^{30}$ Kochenov, 'Behind the Copenhagen Façade'.

${ }^{31}$ Olsen, 'Promotion of Democracy', 144.

${ }_{32}^{32}$ Moravcsik, 'Taking Preferences Seriously', 517.

${ }^{33}$ Falkner, 'Political Economy'; Dür, 'Bringing Economic Interests Back'; Elgström, 'Trade and Aid'.

${ }^{34}$ Bienen, Freund, and Rittberger, 'Societal Interests', 3.

${ }^{35}$ George and Bennett, Case Studies, 81-83; Yin, Case Study Research, 47.

${ }^{36}$ For provisions on participation in environmental policy: Principle 10 of the 1992 Rio Declaration on Environment and Development (non-binding), UNECE Convention on Access to Information, Public Participation in Decision-making and Access to Justice in Environmental Matters 1998 (binding, including weak participation provisions on GMOs in Art. 6.11); in particular with regard to GMOs (transboundary movement): Art. 23 of the 2000 Cartagena Protocol (binding); in particular with regard to water: Protocol on Water and Health to the 1992 Convention on the Protection and Use of Transboundary Watercourses and International Lakes (binding).

${ }^{37}$ Lavenex, 'A Governance Perspective', 939.

${ }^{38}$ King, Keohane, and Verba, Designing Social Inquiry, 140.

${ }^{39}$ For (non-binding) provisions on participation in fisheries policy: FAO Code of Conduct for responsible fisheries 1995: 'States, in accordance with appropriate procedures, should facilitate consultation and the effective participation of industry, fishworkers, environmental and other interested organizations in decision-making with respect to the development of laws and policies related to fisheries management, development, international lending and aid.' (6.13); 'Within areas under national jurisdiction, States should seek to identify relevant domestic parties having a legitimate interest in the use and management of fisheries resources and establish arrangements for consulting them to gain their collaboration in achieving responsible fisheries' (7.1.2).

${ }^{40}$ European Parliament and Council, 'Directive 2003/35/EC'.

${ }^{41}$ European Parliament and Council, 'Decision No 1600/2002/EC', Art. 9.2(i).

${ }^{42}$ Ibid., Art. 6.2(i).

${ }^{43}$ European Commission, 'European Neighbourhood Policy'.

${ }^{44}$ One interview partner mentioned that the European Commission provides comments under the WTO TBT notification procedure on Ukraine (G/TBT/N/UKR/45). There is also some cooperation in TAIEX workshops (e.g. planned TAIEX workshop AGR 42006 on 'Harmonisation of GMO analysis', which, however, does not deal with public participation).

${ }^{45}$ UNECE, 'Report', 3.

${ }^{46}$ The European Commission signed the Aarhus Convention for the European Community on 25 June 1998.

Ratification took place on 17 February 2005.

${ }^{47}$ European Parliament and Council, 'Decision No 1600/2002/EC', Art. 9.2c.

${ }^{48}$ Council, 'Note from Council Secretariat', 2.

${ }^{49}$ Silina and Hontelez, 'Aarhus Convention', 2.

${ }^{50}$ Rosendal, 'Governing GMOs', 90.

${ }^{51}$ Kruszewska, 'Der Wilde Osten'; Zoeller, 'CEE's Experimental Fields'.

${ }_{53}$ Bernauer, Genes, 83; Falkner, Business Power, 153.

${ }_{53}^{53}$ European Commission, 'Innovation and Competitiveness', 32-33; Ramani, 'Creating Incentives', 1996.

${ }_{55}^{54}$ Rosendal, 'Governing GMOs', 93.

${ }^{55}$ Friends of the Earth Europe, 'Too Close'.

${ }^{56}$ Rosendal, 'Governing GMOs', 91-93.

${ }^{57}$ Falkner, Business Power, 159-160; Bernauer, Genes, 81.

${ }^{58}$ Bernauer, Genes, 95.

${ }^{59}$ Val Giddings, 'Letter'.

${ }^{60}$ Verschueren, 'Letter'.

${ }^{61}$ Hontelez, 'Letter'.

${ }^{62}$ Eco-Forum et al., 'Almaty Action Statement'.

${ }^{63}$ Rosendal, 'Governing GMOs', 100. 
${ }^{64}$ Bernauer, Genes, 69.

${ }^{65}$ Ibid., 8.

${ }^{66}$ Kruszewska, 'Der Wilde Osten', Higgins, H. 'Romania', 3.

${ }^{67}$ Pollack and Shaffer, When Cooperation Fails, 177-234.

${ }^{68}$ European Parliament and Council, 'Directive 2000/60/EC', Preamble.

${ }^{69}$ Ibid., Annex VII: A9.

${ }^{70}$ Partzsch, 'European Union Water Policy', 243.

${ }^{71}$ Page and Kaika, 'EU Water Framework Directive', 334-335.

${ }^{72}$ Martin, 'Position Paper'.

${ }^{73}$ European Commission, 'European Neighbourhood and Partnership Instrument', 11.

${ }^{74}$ Mott MacDonald, 'Water Governance', A-3.

${ }^{75}$ Today, there are two major types of agreements. First, there are the agreements based on reciprocal access to the resource (the so-called 'Northern agreements', with the exception of Greenland). Second, there are the agreements where access to the resource is granted in exchange for financial compensation from the EU budget. Such agreements exist mainly with ACP countries but also with Morocco and Greenland ('Southern agreements'). A third type of agreement existed with Argentina but remained the only of its kind (Lequesne, The Politics of Fisheries, 137-38). This article focuses on the agreements of the second type.

${ }^{76}$ Borg, 'A Partner in Global Fisheries'.

${ }^{77}$ European Commission, 'Commission Staff Working Paper SEC(2007) 1202', 86.

${ }^{78}$ European Commission, 'Reflections on Further Reform', 2.

${ }^{79}$ (European Commission/Guinea Bissau, 2008a, 2010; European Commission/Mozambique, 2008; European Commission/Cape Verde, 2009; European Commission/Comoros, 2008; European Commission/Greenland, 2008, 2009; European Commission/Ivory Coast, 2008, 2009; European Commission/Madagascar, 2008; European Commission/Mauritania, 2008, 2010; European Commission/Morocco, 2009, 2010; European Commission/São Tomé et Príncipe, 2007; European Commission/Seychelles, 2009b, 2009a),

http://ec.europa.eu/fisheries/cfp/international/agreements/joint_committees/index_en.htm, last access 15 June 2010.

${ }^{80}$ European Commission, The Common Fisheries Policy, 25.

${ }^{81}$ Council, 'Conclusions on Democracy Support', 1; European Commission, 'European Union's Role in Promoting Human Rights and Democratisation'.

${ }^{82}$ European Commission, 'Integrated Framework for Fisheries', 5, emphasis added.

${ }^{83}$ Council, 'Fisheries Partnership Agreements', Art. 2, p. 15; Council, 'Regulation (EC) No 861/200 ', Art. 7.

${ }^{84}$ Lequesne, 'Fisheries Policy', 373 and 361.

${ }^{85}$ Europêche and COGECA, 'Position', 13.

${ }^{86}$ Europêche and COGECA, 'Answers', 25.

${ }^{87}$ Quoted in Lequesne, 'Fisheries Policy', 373.

${ }^{88}$ Van Hoof and van Tatenhove, 'EU Marine Policy', 728-729.

${ }^{89}$ Churchill and Owen, EC Common Fisheries Policy, 28.

${ }^{90}$ Lequesne, 'Fisheries Policy', 258.

${ }^{91}$ Gorez, 'The Future of Fisheries Partnership Agreements'; West African Artisanal Fisheries' Organisations Representatives, 'Nouakchott Declaration'; European Parliament, 'Report', 17.

${ }^{92}$ Hudson, 'Case Study', 127-128.

${ }^{93}$ ACFA, 'ACFA Opinion', 18.

${ }^{94}$ Schimmelfennig and Scholtz, EU Democracy Promotion.

${ }^{95}$ Freyburg et al. 'EU Promotion of Democratic Governance'.

${ }^{96}$ The present paper does not allow to make inferences about the magnitude of external actors' influence. While they may have a reinforcing effect it is beyond the scope of the paper to measure these effects.

\section{Note on contributor}

Anne Wetzel is post-doctoral researcher at the Centre for EU Studies, Ghent University, Belgium.

\section{Bibliography}

Advisory Committee on Fisheries and Aquaculture (ACFA). 'ACFA Opinion on the Commission Green Paper concerning the Reform of the CFP (COM(2009)163)'. EP(09)158 final. 9 December 2009. 
Andrés Viñas, David.'EU's Democracy Promotion Policy in the Mediterranean: Squaring the Stability-Democracy Circle?'. Working Paper of Observatorio of European Foreign Policy 80, 2009.

Beetham, David. Democracy and Human Rights. Cambridge: Polity Press.

Bernauer, Thomas. Genes, Trade, and Regulation. The Seeds of Conflict in Food Biotechnology. Princeton: Princeton University Press, 2003.

Bienen, Derk, Corinna Freund and Volker Rittberger. 'Societal Interests, Policy Networks and Foreign Policy: An Outline of Utilitarian-Liberal Foreign Policy Theory'. Tübinger Arbeitspapiere zur Internationalen Politik und Friedensforschung 34, 2000.

Borg, Joe. 'A Partner in Global Fisheries and Beyond: The European Union's Drive for the Sustainable Management of Our Oceans and Seas', Address at Shanghai Fishery University on 10.11.2007.

Churchill, Robin and Daniel Owen. The EC Common Fisheries Policy. Oxford: Oxford University Press, 2010.

Council of the European Union. (2001). 'General Affairs Council Conclusions on Human Rights and Democratisation in Third Countries'. 10228/01 (Presse 250 - G). 25 June 2001

Council of the European Union. 'Council Regulation (EC) No 2371/2002 of 20 December 2002 on the Conservation and Sustainable Exploitation of Fisheries Resources under the Common Fisheries Policy.' Official Journal of the European Communities L 358 (31.12.2002), 59-80.

Council of the European Union. (2004). 'Fisheries Partnership Agreements with Third Countries - Council Conclusions'. 11234/2/04 REV 2 (Presse 221), C/04/221. 19 July 2004.

Council of the European Union. (2005). 'Note from Council Secretariat to Council. Adoption of a Council Decision Concerning the Participation of the European Community in Negotiations on Genetically Modified Organisms under the Convention on Access to Information, Public Participation in Decision-Making and Access to Justice in Environmental Matters, including the Second Meeting of the Parties (Almaty, Kazakhstan, 25 - 27 May 2005)'. 6889/05 RESTREINT UE. 3 March 2005.

Council of the European Union. 'Council Regulation (EC) No 861/2006 of 22 May 2006

Establishing Community Financial Measures for the Implementation of the Common Fisheries Policy and in the Area of the Law of the Sea. Official Journal of the European Union L 160 (14.06.2006), 1-11.

Council of the European Union. 'Council Conclusions on Democracy Support in the EU's External Relations'. 2974th External Relations Council Meeting. 17 November 2009. Crawford, Gordon.'The European Union and Democracy Promotion in Africa: The Case of Ghana'. The European Journal of Development Research 17, no. 4 (2005): 571-600.

Dür, Andreas (2008). Bringing Economic Interests Back Into the Study of EU Trade PolicyMaking. British Journal of Politics \& International Relations 10, no. 1 (2008): 27-45.

Eco-Forum et al. 'The Almaty Action Statement. Statement of the European Eco-Forum and Other Civil Society Organizations of the UN-ECE Region'. 23 May 2005.

Elgström, O. (2009). 'Trade and Aid? The Negotiated Construction of EU Policy on Economic Partnership Agreements'. International Politics 46, no. 4 (2009): 451-68. European Commission. 'Communication from the Commission to the Council and the European Parliament. The European Union's Role in Promoting Human Rights and Democratisation in Third Countries'. COM(2001) 252 final. 8 May 2001.

European Commission. 'Communication from the Commission on an Integrated Framework for Fisheries Partnership Agreements with Third Countries'. COM(2002) 637 final. 23 December 2002. 
European Commission. 'Innovation and Competitiveness in European Biotechnology'.

Brussels: Enterprise Directorate-General: Enterprise Papers, no. 7. 2002.

European Commission. 'Communication from the Commission: European Neighbourhood

Policy. Strategy Paper'. COM(2004) 373 final. 12 May2004.

European Commission. 'Communication from the Commission: Governance in the European

Consensus on Development. Towards a Harmonised Approach within the European

Union'. COM(2006) 421 final. 30 August 2006.

European Commission. 'Commission Staff Working Paper Accompanying the Commission

Working Paper 'EU Report on Policy Coherence for Development'. SEC(2007) 1202.

20 September 2007.

European Commission. 'European Neighbourhood and Partnership Instrument. ENPI Eastern

Regional Indicative Programme 2007-2010'. 2007.

European Commission. 'Commission Working Document. Reflections on further Reform of the Common Fisheries Policy'. 17 September 2008.

European Commission. The Common Fisheries Policy. A user's guide. Luxembourg: Office for Official Publications of the European Communities, 2009.

European Commission and Council of the European Union - General Secretariat. 'Joint Paper on Democracy Building in EU External Relations'. SEC(2009) 1095 final. 27 July 2009.

European Commission/Cape Verde. 'Accord de Partenariat dans le Secteur de la Pêche, 1ère Commission Mixte - Procès Verbal'. 18-19 June 2009.

European Commission/Comoros. 'Accord de Partenariat dans le Secteur de la Pêche, 2ième Commission Mixte - Procès Verbal'. 17-18 September 2008.

European Commission/Greenland. 'Fisheries Partnership Agreement, Joint Committee Meeting - Minutes'. 25 November 2008.

European Commission/Greenland. (2009). 'Fisheries Partnership Agreement, Joint Committee Meeting - Minutes'. 18 March 2009.

European Commission/Guinea Bissau. 'Accord de Partenariat dans le Secteur de la Pêche, 1ère Commission Mixte - Procès Verbal'. 3-4 July 2008.

European Commission/Guinea Bissau. 'Accord de pêche CE/Guinée-Bissau 2007-2011, Matrice de 1'Appui au Secteur de la Pêche - Années 2008-2011'. 2008.

European Commission/Guinea Bissau. 'Accord de Partenariat dans le Secteur de la Pêche, Commission Mixte - Procès Verbal'. 11-12 March 2010.

European Commission/Ivory Coast. 'Accord de Partenariat dans le Secteur de la Pêche, 1ère Commission Mixte - Procès Verbal.' 17-18 July 2008.

European Commission/Ivory Coast. Accord de Partenariat dans le Secteur de la Pêche, 2ème Commission Mixte - Procès Verbal. 28-29 May 2009.

European Commission/Madagascar. 'Accord de Partenariat dans le Secteur de la Pêche, 2ième Commission Mixte - Procès Verbal'. 14-15 April 2008.

European Commission/Mauritania. 'Rapport de la Seconde Réunion du Comité Scientifique Conjoint RIM-UE'. 8-10 October 2008.

European Commission/Mauritania. 'Accord de Partenariat dans le Secteur de la Pêche. Résumé du Procès Verbal de la Commission Mixte. 22-25 March 2010.

European Commission/Morocco. 'Procès Verbal de la Quatrième Commission Mixte de l'Accord de Partenariat dans le Secteur de la Pêche'. 1-3 April 2009.

European Commission/Morocco. 'Procès verbal de la cinquième Commission Mixte de l'Accord de Partenariat dans le Secteur de la Pêche'. 2-3 February 2010.

European Commission/Mozambique. 'Fisheries Partnership Agreement, Minutes of the First Joint Committee'. 6 November 2008. 
European Commission/São Tomé et Príncipe. 'Procès Verbal de la 1ère Commission Mixte de l'Accord de Partenariat de Pêche. 8-9 February 2007.

European Commission/Seychelles. 'Fisheries Partnership Agreement, Joint Committee Agreed Minutes'. 5-6 February 2009.

European Commission/Seychelles. 'Fisheries Partnership Agreement, Joint Committee Agreed Minutes'. 12 January 2009.

European Parliament. Report on the Commission Communication on an Integrated Framework for Fisheries Partnership Agreements with Third Countries (COM(2002) 637) - (2003/2034(INI))'. A5-0303/2003 final. 11 September 2003.

European Parliament and Council of the European Union. 'Directive 2000/60/EC of 23 October 2000 Establishing a Framework for Community Action in the Field of Water Policy. Official Journal of the European Communities L 327 (22.12.2000): 1-72.

European Parliament and Council of the European Union. 'Directive 2001/18/EC of 12 March 2001 on the Deliberate Release into the Environment of Genetically Modified Organisms and Repealing Council Directive 90/220/EEC'. Official Journal of the European Communities L 106 (17.04.2001): 1-38.

European Parliament and Council of the European Union. 'Decision No 1600/2002/EC of 22 July 2002 Laying down the Sixth Community Environment Action Programme'. Official Journal of the European Communities L 242 (10.09.2002): 1-15.

European Parliament and Council of the European Union. 'Directive 2003/35/EC of 26 May 2003 Providing for Public Participation in Respect of the Drawing up of Certain Plans and Programmes Relating to the Environment and Amending with Regard to Public Participation and Access to Justice Council Directives 85/337/EEC and 96/61/EC'. Official Journal of the European Union L 156 (25.06.2003): 17-24.

European Parliament and Council of the European Union. 'Regulation EC No 1829/2003 of 22 September 2003 on Genetically Modified Food and Feed.' Official Journal of the European Union L 268 (18.10.2003): 1-23.

Europêche and COGECA. 'Position by Europêche and COGECA on the Green Paper Presented by the Commission on the Future of the Common Fisheries Policy'. CP(01)75F1-EP(01)33. 12 July 2001.

Europêche and COGECA. 'Answers to the Questions in the Green Paper on the Reform of the Common Fisheries Policy'. EP(09)89final/SP(09)3074:5. 14 October 2009.

Falkner, Robert. (2007). 'The Political Economy of 'Normative Power' Europe: EU Environmental Leadership in International Biotechnology Regulation'. Journal of European Public Policy 14, no. 4 (2007): 507-26.

Falkner, Robert. Business Power and Conflict in International Environmental Politics. New York: Palgrave Macmillan, 2008

Freyburg, Tina, Sandra Lavenex, Frank Schimmelfennig, Tatiana Skripka, and Anne Wetzel. 'EU Promotion of Democratic Governance in the Neighbourhood'. Journal of European Public Policy 16, no. 6 (2009): 916-34.

Freyburg, T., Tatiana Skripka, and Anne Wetzel. 'Democracy between the Lines? EU Promotion of Democratic Governance via Sector-Specific Co-Operation'. Zurich: NCCR Working Paper 5. 2007.

Friedrich, Dawid 'Old Wine in New Bottles? The Actual and Potential Contribution of Civil Society Organisations to Democratic Governance in Europe'. Oslo: RECON Online Working Paper 2007/08. 2007.

Friends of the Earth Europe. 'Too Close for Comfort. The Relationship between the Biotech Industry and the European Commission. An Analysis'. Brussels. 2007.

George, Alexander. L. and Andrew Bennett. Case Studies and Theory Development in the Social Sciences. Cambridge, Massachusetts, London: MIT Press, 2005. 
Gorez, Béatrice. 'The Future of Fisheries Partnership Agreements in the Context of the Common Fisheries Policy Reform'. Presentation to the European Parliament Development Committee. 2 September 2009.

Held, David. Models of Democracy. Cambridge: Polity, third edition, 2006.

Higgins, Holly. 'Romania. Planting seeds. Romanian legislation for GMO seeds'. USDA Foreign Agricultural Service. GAIN Report \#RO0005. 28 February 2000.

Hontelez, John. 'Letter to the Environment Ministers of the EU Member States and Accession Countries Concerning the Aarhus Convention and Public Participation in Decision Making on GMOs'. 18 September 2003.

Hudson, Alan. 'Case Study of the Fisheries Partnership Agreements'. In Policy Coherence for Development in the EU. Council Strategies for the Way Forward, ed. Louise van Schaik et al., 124-29. Brussels: Centre for European Policy Studies, 2006.

Jünemann, Anette. 'From the Bottom to the Top: Civil Society and Transnational NGOs in the Euro-Mediterranean Partnership'. Democratization 9, no. 1 (2002): 87-105.

Jünemann, Anette and Michèle Knodt. 'Explaining EU Instruments and Strategies of EU Democracy Promotion. Concluding Remarks'. In Externe Demokratieförderung durch die Europäische Union, ed. Anette Jünemann and Michèle Knodt, 353-69. BadenBaden: Nomos, 2007.

Kaufmann, Daniel, Aart Kraay, and Massimo Mastruzzi. 'Aggregate and Individual Governance Indicators 1996-2008'. The World Bank Policy Research Working Paper 4978 (2009).

King, Gary, Robert Owen Keohane, and Sidney Verba. Designing Social Inquiry: Scientific Inference in Qualitative Research. Princeton: Princeton University Press, 1994.

Kochenov, Dimitry. 'Behind the Copenhagen Façade. The Meaning and Structure of the Copenhagen Political Criterion of Democracy and the Rule of Law'. European Integration online Papers 8, no. 10 (2004).

Kruszewska, Iza. 'Der Wilde Osten. Zur Einführung der Gentechnik in Mittel- und Osteuropa'. politische ökologie 81-82 (2003).

Lavenex, Sandra. 'EU External Governance in 'Wider Europe', Journal of European Public Policy 11, no. 4 (2004): 680-700.

Lavenex, Sandra. 'A Governance Perspective on the European Neighbourhood Policy: Integration Beyond Conditionality?' Journal of European Public Policy 15, no. 6 (2008): 938-55.

Lequesne, Christian. The Politics of Fisheries in the European Union. Manchester: Manchester University Press, 2004

Lequesne, Christian. 'Fisheries Policy. Letting the Little Ones Go?' In Policy-Making in the European Union, Helen Wallace, William Wallace and Mark. A. Pollack, 353-76. Oxford: Oxford University Press, 2005.

Maier, Sylvia and Frank Schimmelfennig. 'Shared Values: Democracy and Human Rights'. In Governing Europe's Neighbourhood: Partners or Periphery?, ed. Katja Weber, Michael E. Smith and Michael Baun, 39-57. Manchester: Manchester University Press, 2007.

Martin, Lloyd. 'Position Paper by the International Private Sector on its Role in the Reform of Water and Wastewater Utilities in Eastern Europe, Caucasus and Central Asia. In Financing Water Supply and Sanitation in Eastern Europe, Caucasus and Central Asia, 221-31. Paris: Organisation for Economic Co-operation and Development, 2006.

Moravcsik, Andrew. 'Taking Preferences Seriously: A Liberal Theory of International Politics'. International Organization 51, no. 4 (1997): 513-53.

Mott MacDonald. 'Water Governance in the Western EECCA Countries'. TACIS/2008/137153 (EC), Inception Report - Final. 2008. 
Olsen, Gorm Rye. 'Promotion of Democracy as a Foreign Policy Instrument of 'Europe': Limits to International Idealism'. Democratization 7, no. 2 (2000): 142-67.

Olsen, Gorm Rye. 'The European Union: An Ad Hoc Policy with a Low Priority'. In Exporting Democracy. Rhetoric vs. Reality, ed. Peter J. Schraeder, 131-45. Boulder: Lynne Rienner, 2002.

Orbie, Jan. 'Civilian Power Europe. Review of the Original and Current Debates'. Cooperation and Conflict 41, no. 1 (2006): 123-28.

Page, Ben and Maria Kaika. 'The EU Water Framework Directive. Part 2. Policy Innovation and the Shifting Choreography of Governance'. European Environment 13 (2003): 328-43.

Partzsch, Lena (2009). 'European Union Water Policy: To Transition or Not to Transition? Coalitions as Key'. In Water Policy Entrepreneurs. A Research Companion to Water Transitions Around the Globe, ed. Dave Huitema \& Sander Meijerink, 237-49. Cheltenham: Edward Elgar, 2009.

Pollack, Mark. A. and Gregory C. Shaffer. C. When Cooperation Fails: The International Law and Politics of Genetically Modified Foods. Oxford: Oxford University Press, 2009.

Powel, Brieg Tomos. 'A Clash of Norms: Normative Power and EU Democracy Promotion in Tunisia'. Democratization 16, no. 1 (2009): 193-214.

Ramani, Shyama. 'Creating Incentives: A Comparison of Government Strategies in India and France'. Biotechnology and Development Monitor 26 (1996): 18-21.

Rosendal, G. Kristin. 'Governing GMOs in the EU: a Deviant Case of Environmental PolicyMaking?' Global Environmental Politics 5, no. 1(2005): 82-104.

Schimmelfennig, Frank. 'Europeanization Beyond Europe'. Living Reviews in European Governance 2, no.1 (31.07.2007).

Schimmelfennig, Frank and Hanno Scholtz. 'EU Democracy Promotion in the European Neighborhood. Political Conditionality, Economic Development and Transnational Exchange'. European Union Politics 9, no. 2 (2008): 187-215.

Schmidt, Manfred G. Demokratietheorien. Wiesbaden: Verlag für Sozialwissenschaften, 4th edition, 2008.

Schmitter, Philippe. C. 'Participation in Governance Arrangements: Is There a Reason to Expect it Will Achieve 'Sustainable and Innovative Policies in a Multi-Level Context'?' In Participatory Governance. Political and Societal Implications, ed. Jürgen R. Grote and Bernard Gbikpi, 51-69. Opladen: Leske+Budrich, 2002.

Schraeder, Peter. J. 'The State of the Art in International Democracy Promotion: Results of a Joint European-North American Research Network'. Democratization 10, no. 2 (2003): 21-44.

Silina, Mara and John Hontelez. 'Why the EU Needs to Take the Aarhus Convention More Seriously!' Metamorphosis no. 37 (2005): 1-2.

Smith, Karen. E. European Union Foreign Policy in a Changing World. Cambridge: Polity, 2008.

Snyder, Jack. From Voting to Violence: Democratization and Nationalist Conflict. New York: Norton, 2000.

UNECE. 'Report of the Second Meeting of the Working Group on Genetically Modified Organisms'. MP.PP/AC.2/2003/4. Geneva. 2003.

Val Giddings, L. 'Letter to the Aarhus Convention Secretariat'. 10 June 2003.

van Hoof, Luc and Jan van Tatenhove. 'EU Marine Policy on the Move: The Tension Between Fisheries and Maritime Policy'. Marine Policy 33, no. 4 (2009): 726-32.

Verba, S. Small Groups and Political Behavior. Princeton: Princeton University Press, 1961. 
Verba, Sidney. 'Democratic Participation'. The Annals of the American Academy of Political and Social Science 373, no. 1 (1967): 53-78.

Verschueren, Christian. 'Letter to the Aarhus Convention Secretariat'. CV/ml/04-0153. 4 February 2004.

Warkotsch, Alexander. 'Non-Compliance and Instrumental Variation in EU Democracy Promotion'. Journal of European Public Policy 15, no. 2 (2008): 227-45.

West African Artisanal Fisheries' Organisations Representatives. 'Nouakchott Declaration of West Africa Artisanal Fisheries Sector Organisations'. Nouakchott. 11 November 2009.

Yin, Robert K. Case Study Research: Design and Methods. Thousand Oaks, London, New Delhi: Sage, 2003.

Youngs, Richard. 'The European Union and Democracy Promotion in the Mediterranean: A New or Disingenuous Strategy?' In The European Union and Democracy Promotion. The Case of North Africa, ed. Richard Youngs and Richard Gillespie, 40-62. London: Frank Cass, 2002.

Zoeller, R. 'CEE's Experimental Fields'. Finance New Europe (November 2006).

Table 1: EU participatory governance promotion

\begin{tabular}{|l|c|c|c|}
\hline & $\begin{array}{l}\text { GMO - Eastern European } \\
\text { ENP countries }\end{array}$ & $\begin{array}{c}\text { Water - Eastern European } \\
\text { ENP countries }\end{array}$ & Fisheries - FPA \\
\hline Acquis & $\begin{array}{c}\text { Issue specific, } \\
\text { internationally embedded }\end{array}$ & $\begin{array}{c}\text { Issue specific, } \\
\text { internationally embedded }\end{array}$ & $\begin{array}{c}\text { Issue specific, } \\
\text { internationally embedded }\end{array}$ \\
\hline Interdependence & Not unfavourable for EU & Not unfavourable for EU & Not unfavourable for EU \\
\hline Security & Close & Low politics & Low politics \\
\hline Proximity & $\begin{array}{c}\text { Close } \\
\text { Environmental NGOs) } \\
\text { (external actors), Trade } \\
\text { lobby }\end{array}$ & $\begin{array}{c}\text { No significant adverse } \\
\text { interests }\end{array}$ & $\begin{array}{c}\text { Catching sector (vs. } \\
\text { Development NGOs) }\end{array}$ \\
\hline $\begin{array}{l}\text { Interests } \\
\text { Participatory governance } \\
\text { promotion }\end{array}$ & \multicolumn{1}{|c|}{+} & \\
\hline
\end{tabular}

